\title{
A comparative study for energetic valorisation of partially digested sewage sludge
}

\author{
A. Alonso-Vicario ${ }^{1}$, A. M. Macarulla-Arenaza ${ }^{1}$, I. Oribe-García ${ }^{1}$ \\ \& A. Macarulla-Arenaza ${ }^{2}$ \\ ${ }^{I}$ Deusto Institute of Technology, DeustoTech Energy, \\ University of Deusto, Spain \\ ${ }^{2}$ Aguas del Añarbe-Añarbeko Urak SA, Spain
}

\begin{abstract}
The common final disposition of the sewage sludge obtained after anaerobic digestion is often use in agricultural soils or as a substitute to fossil fuels in clinker kilns, whose heating value is about a quarter of the coke or peat. In this paper, a comparative study between incineration and gasification with $\mathrm{CO}_{2}$ as oxidant agent has been carried out. After the physical and chemical characterization of the sludge, the combustion and gasification properties have been studied by means of thermogravimetric analysis. According to the combustion profile, while the ignition temperature $\left(200^{\circ} \mathrm{C}\right)$ and peak temperature $\left(288^{\circ} \mathrm{C}\right)$ are of the order of any kind of plant biomass, the maximum combustion velocity is much lower, arround $0.25 \mathrm{mg} / \mathrm{min}$. Moreover, although gasification requires higher temperatures (around $790^{\circ} \mathrm{C}$ ) for the complete transformation of the organic matter, the resulting gas, with a heating value much higher than that contained in the dried sludge, may be used in the wastewater treatment plant, reducing both the gas natural requirements and the final sludge volume by $37 \%$, and consequently the costs associated with the transport. The final inorganic matter may be also incorporate directly into construction materials, closing the whole loop.

Keywords: biomass, waste, sludge, energetic valorisation, co-combustion, gasification.
\end{abstract}




\section{Introduction}

Current global energy outline based on the use of fossil fuels is a threat of ecological catastrophe in the short term, on one side by their depletion by uncontrolled and irrational use today and on the other by exceeding the limits of the Earth's capacity to absorb its impact.

Another important source of pollution is industrial waste, which without proper treatment is very harmful to the Earth's ecosystem. Therefore, it is necessary to find alternative solutions that contribute to its minimization and finally its complete elimination, without endangering other social and economic factors. It is therefore imperative to find renewable sources of raw materials and to develop green technologies that address the current energy crisis and pollution problems.

Wastewater treatment is not getting left behind in this issue. The progressive implementation of Directive 91/271/EEC, as well as the slow but steady growth of households connected to sewage treatment plants and the increased level of treated water quality has increased the amount of sludge to landfill (5.5 million tones of dry matter in 1992 to 9 million tons in 2005).

The use of waste to energy technologies allows us to increase the flexibility of the national/regional energy systems, as well as the production of renewable energy. However, in general, the characteristics of most of this waste is not suitable to replace conventional fuels, so that transformation into higher energy density fuel is necessary. The fuels thus obtained have the following advantages: lower emissions of sulfur, slag not burning, low ash content, and contributing to improving the quality of the environment. So, biomass is converted to heat, fuels or electricity. These transformations can be divided into two groups:

- Thermo-chemical processes: chemical transformation that takes place under high temperatures and excess oxygen (combustion) [1]; limited amounts of oxidant agents, such as $\mathrm{O}_{2}$, water or $\mathrm{CO}_{2}$ (gasification) [2] or the lack of it (pyrolysis) [3].

- Biochemical processes: degradation of complex molecules to simpler molecules with high energy density carried out by microorganisms, the most commonly used are alcoholic fermentation [4] and anaerobic digestion $[5,6]$, to produce ethanol and biogas, respectively.

The Wastewater Treatment Plant of Aguas del Añarbe, SA (Loyola, Spain), was designed for the treatment of urban wastewater by anaerobic digestion, so that partially recovers the energy content of sludge in the form of biogas, which is fed to a cogeneration system together with natural gas. Heat is used for the drying and dehydration phases in the sludge line, and electricity for both consumption and for sale. Moreover, the final dried sludge shows low biological activity in very low volume.

However, the wastewater treatment plant produces 10 tons/day of final partially digested and dried sludge, and it is expected that production will increase to 30-40 tons/day in the near future. Therefore, it is necessary to find alternative solutions for the biosolid whose production is expected to grow exponentially in the coming years. 
Among the thermochemical processes, co-combustion with fossil fuels offers economic and environmental benefits [7-9], contributing to reducing total pollutant emissions per unit of energy produced, as $\mathrm{CO}_{2}$ emissions from biomass is not counted in the overall calculation, and also reduces both $\mathrm{NO}_{\mathrm{x}}$ and $\mathrm{SO}_{\mathrm{x}}$ levels on existing coal plants. Thus, biomass is usually burned in conventional power plants with steam cycles, as it was some years ago in the sugar mills [10].

In contrast, gasification is applied in more advanced and efficient systems. The gases obtained in the gasification can be used in heating processes by direct combustion or in internal combustion engines or even in gas turbines, systems that are between 10 and $15 \%$ more efficient than direct combustion of any solids and also less polluting [11], or even in more efficient systems that integrate fuel cells $[12,13]$.

In this paper, after a previous physical and chemical characterization of the final dried and partially digested sludge, a comparative study between combustion and gasification using carbon dioxide has been carried out by means of thermogravimetric analysis in order to demonstrate the environmental, technical and economic advantages of their use as an alternative fuel.

\section{Experimental}

The characterization of the biosolid has been carried out in order to know the physico-chemical properties that determine its performance as fuel by energetic valorisation. For this purpose, the following analytical methods have been used: CEA 1424, CEA 1281 and CEA 1358 standard methods for elemental analysis; drying at $105^{\circ} \mathrm{C}$, and gravimetry for immediate analysis; colorimetry, atomic absorption and atomic emission spectroscopy for the determination of heavy metal and inorganic content; granulometry has been mesured according to Directive 87/94/CEE; and the higher heating value following the CEA 1235 standard method.

In order to analyse microscopic properties, reactivity studies were carried out by thermogravimetry using a SETARAM Setsys Evolution thermobalance. These tests were carried out by The General Research Services of the "Instituto de Carboquímica" (ICB) of Zaragoza. Samples were heated with a temperature ramp of $10^{\circ} \mathrm{C} / \mathrm{min}$ under oxidant atmosphere (with air from room temperature up to $1200^{\circ} \mathrm{C}$, and $5 \% \mathrm{CO}_{2}$ in $\mathrm{Ar}$ from room temperature up to $900^{\circ} \mathrm{C}$ ), followed by isotherm for $10 \mathrm{~min}$.

\section{Results}

In general, biomass is much less dense than coal $\left(500 \mathrm{~kg} / \mathrm{m}^{3}\right.$ vs. $\left.1300 \mathrm{~kg} / \mathrm{m}^{3}\right)$ [14]. It is also much more difficult to reduce to small sizes. Biomass with coal burning cannot have a particle size greater than $6.3 \mathrm{~mm}$ (carbon $0.1 \mathrm{~mm}$ ) [14]. Table 1 shows the result of the fineness of the sludge, $99.9 \%$ is below $5 \mathrm{~mm}$, thus ensuring its use as a supplement to coal.

Tables 2, 3 and 4 summarize the main results of the chemical characterization of the biosolid. The results of the analysis of metal content and elemental 
Table 1: $\quad$ Granulometry of sludge.

\begin{tabular}{|c|c|}
\hline Granulometry & $\%$ \\
\hline$>5 \mathrm{~mm}$ & 0.1 \\
\hline $4-5 \mathrm{~mm}$ & 1.0 \\
\hline $3-4 \mathrm{~mm}$ & 26.2 \\
\hline $2-3 \mathrm{~mm}$ & 60.9 \\
\hline $1-2 \mathrm{~mm}$ & 11.3 \\
\hline $0.5-1 \mathrm{~mm}$ & 0.1 \\
\hline$<0.5 \mathrm{~mm}$ & 0.1 \\
\hline Stones and gravel in diameter $>5 \mathrm{~mm}$ & $<5$ \\
\hline Impurities: metals, glass and plastic $>2 \mathrm{~mm}$ & $<3$ \\
\hline
\end{tabular}

Table 2: $\quad$ Elemental analysis.

\begin{tabular}{|c|c|c|c|c|c|c|c|}
\hline$\% \mathrm{dm}$ & $\mathrm{C}$ & $\mathrm{H}$ & $\mathrm{N}$ & $\mathrm{S}$ & $\mathrm{Cl}$ & Ash & $\mathrm{O}$ (diff.) \\
\hline Sludge & 20.7 & 3.3 & 2.1 & 0.8 & 0.3 & 75.7 & 10.8 \\
\hline
\end{tabular}

Table 3: $\quad$ Heavy metal content.

\begin{tabular}{|c|c|c|c|c|c|c|c|}
\hline ppm & $\mathrm{Pb}$ & $\mathrm{Ni}$ & $\mathrm{Cd}$ & $\mathrm{Cr}$ & $\mathrm{Zn}$ & $\mathrm{Cu}$ & $\mathrm{Hg}$ \\
\hline Sludge & 60.1 & 26.5 & 0.8 & 59.0 & 256.5 & 103.9 & 0.4 \\
\hline
\end{tabular}

Table 4: $\quad$ Analysis of the inorganic matter.

\begin{tabular}{|c|c|c|c|c|c|c|c|}
\hline$\% d m$ & $\mathrm{Fe}_{2} \mathrm{O}_{3}$ & $\mathrm{CaO}$ & $\mathrm{MgO}$ & $\mathrm{Na}_{2} \mathrm{O}$ & $\mathrm{K}_{2} \mathrm{O}$ & $\mathrm{SO}_{3}$ & $\mathrm{P}_{2} \mathrm{O}_{5}$ \\
\hline Sludge & 6.6 & 13.7 & 0.9 & 0.3 & 0.9 & 2.1 & 2.3 \\
\hline
\end{tabular}

analysis are consistent with those found in the literature for this type of sludge $[15,16]$, with recorded values within an acceptable range to be partially digested sludge. Thus, the content of $\mathrm{C}$ and $\mathrm{H}$ are low, and its relationship (7.1) slightly lower compared to the initial (10.0) of undigested sludge. A low sulfur content (lower than on coal) translates to lower emissions of $\mathrm{SO}_{\mathrm{x}}$, although the nitrogen content is substantially higher, and therefore, the $\mathrm{NO}_{\mathrm{x}}$ emissions.

In general, the biomass has high oxygen content, even in the case of sludge despite its higher content of inorganic matter.

On the other hand, coal shows higher iron content, while plant biomass has higher potassium content than coal and sludge, but similar contents of iron, calcium, magnesium, phosphorus and chlorine than sludge. The moisture content of sludge $(4.2 \%)$ is even lower than coal $(4.8 \%)$.

Also remarkable is the highest $\mathrm{CaO}$ content of the sludge on coal $(5.5 \%)$. $\mathrm{CaO}$ is directly related to the ability of the ashes to adsorb sulfur and nitrogen by formation of the corresponding sulphates and nitrates, which is an advantage of the use of sludge as alternative fuel [17-19]. 
The higher heating value of sludge is $8.8 \mathrm{MJ} / \mathrm{kg}$, above the crust $(\mathrm{HHV}=$ $5.9 \mathrm{MJ} / \mathrm{kg}$ ), the order of sawdust or straw (HHV $=8.4$ and $12.5 \mathrm{MJ} / \mathrm{kg}$ ), half those of wood or sunflower husks, and about a quarter of that of coke or peat.

Figures 1 and 2 show the results of the thermogravimetric analysis with air and carbon dioxide (5\% in Ar), respectively, and Tables 5 and 6 show the results of the deconvolution of the previous graphs.

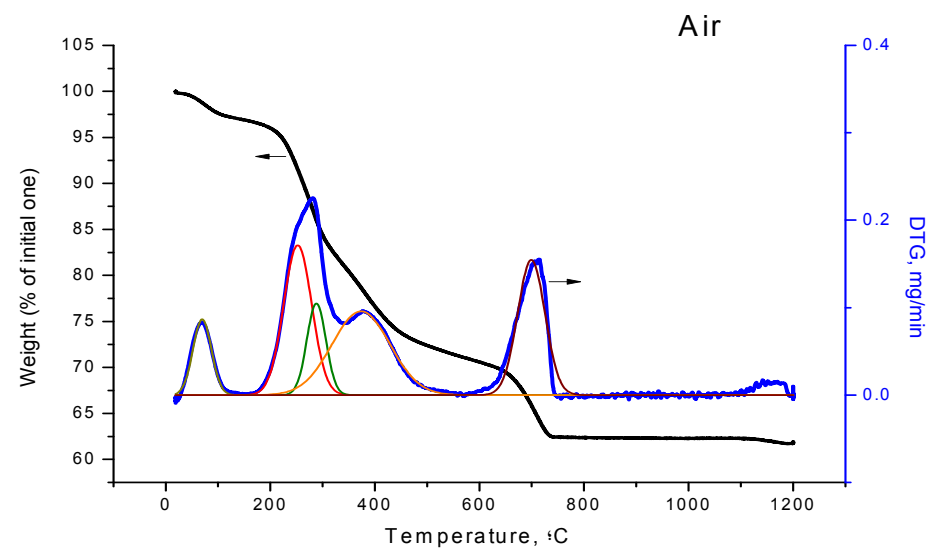

Figure 1: Thermogravimetric analysis of the combustion of the sludge.

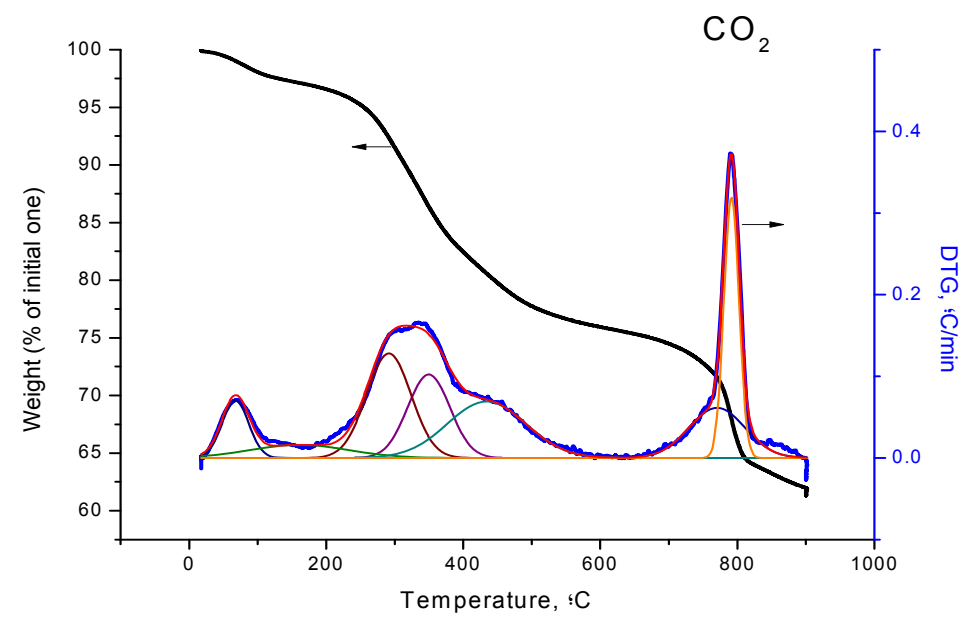

Figure 2: Thermogravimetric analysis of the activation of the sludge with $\mathrm{CO}_{2}$. 
Table 5: $\quad$ Results of the deconvolution of the combustion graph.

\begin{tabular}{|c|c|c|c|}
\hline Peak & T $\max ,{ }^{\circ} \mathrm{C}$ & Area, $\%$ & $\begin{array}{c}\text { Loss of weight } \\
(\mathrm{g} / 100 \mathrm{~g} \text { sludge })\end{array}$ \\
\hline 1 & 70 & 8.8 & 3.4 \\
\hline 2 & 252 & 26.5 & 10.1 \\
\hline 3 & 288 & 11.0 & 4.2 \\
\hline 4 & 373 & 30.6 & 11.7 \\
\hline 5 & 699 & 23.2 & 8.8 \\
\hline Total & -- & 100 & 38.1 \\
\hline
\end{tabular}

Table 6: Results of the deconvolution of the gasification graph.

\begin{tabular}{|c|c|c|c|}
\hline Peak & $\mathrm{T} \mathrm{max}^{\circ}{ }^{\circ} \mathrm{C}$ & Area, $\%$ & $\begin{array}{c}\text { Loss of weight } \\
(\mathrm{g} / 100 \mathrm{~g} \text { sludge })\end{array}$ \\
\hline 1 & 68 & 6.8 & 2.6 \\
\hline 2 & 161 & 5.7 & 2.2 \\
\hline 3 & 291 & 21.1 & 8.0 \\
\hline 4 & 350 & 16.0 & 6.1 \\
\hline 5 & 434 & 20.0 & 7.6 \\
\hline 6 & 770 & 12.7 & 4.8 \\
\hline 7 & 791 & 17.7 & 6.8 \\
\hline Total & -- & 100 & 38.1 \\
\hline
\end{tabular}

The first peak in the profile corresponds to combustion of the sludge moisture; about 3.3\%. After removing the moisture, several peaks occur as a result of the desorption of adsorbed gases.

Between 200 and $500^{\circ} \mathrm{C}$ there is a sudden loss of mass: about $68 \%$ of the total loss experienced during the test, which represents the formation of volatile and their ignition.

Another peak in a smaller size but not least appears at very high temperatures near $700^{\circ} \mathrm{C}$, probably due to partially charred residue.

The ignition temperature is the point at which the profile of combustion shows a sudden increase, in this case at $200^{\circ} \mathrm{C}$, the order of any plant biomass $\left(203^{\circ} \mathrm{C}\right.$ for shells of sunflowers and pine cones, $190^{\circ} \mathrm{C}$ for seeds, rapeseed or $200^{\circ} \mathrm{C}$ for olive refuse [20]).

The point of combustion curve for the rate of weight loss is known as high temperature peak and is indicative of the reactivity of the sample. This temperature is $288^{\circ} \mathrm{C}$, the order of the shells of sunflower $\left(300^{\circ} \mathrm{C}\right)$, rapeseed $\left(262^{\circ} \mathrm{C}\right)$, the pine cones $\left(292^{\circ} \mathrm{C}\right)$, or olive refuse $\left(264^{\circ} \mathrm{C}\right)$. The maximum 
combustion rate, is $0.25 \mathrm{mg} / \mathrm{min}$, much lower than that of the aforementioned types of biomass $(5.5,2.8,5.2$, and $3.4 \mathrm{mg} / \mathrm{min}$, respectively [20]).

As for the gasification analysis with carbon dioxide, as can be seen in Figure 2 and Table 8 , there are three regions or temperature ranges with loss of mass: $25-100^{\circ} \mathrm{C}(4.8 \%), 200-600^{\circ} \mathrm{C}(23.9 \%)$ and $700-850^{\circ} \mathrm{C}(11.6 \%)$. The first one corresponds to the loss of moisture by heating the sample. The other two are a direct consequence of the gasification, requiring at least a temperature of $790^{\circ} \mathrm{C}$ for a residence time long enough for the complete gasification, or $900^{\circ} \mathrm{C}$ and shorter times, which will affect the composition of the final synthesis gas.

In Figure 2 a loss of approximately $37 \%$ of mass after the test can also be observed which coincides with the total organic content of the sludge obtained in the combustion tests. This means that the gasification of the sludge results from a practically complete transformation of the organic content of the sludge to medium power combustible gas (synthesis gas is composed primarily of methane, carbon monoxide and hydrogen) with a much higher heating value (39.9 and $120 \mathrm{MJ} / \mathrm{kg}$, for natural gas and $\mathrm{H}_{2}$, respectively) than sludge $(8.8 \mathrm{MJ} / \mathrm{kg})$. Due to this, it would be interesting to consider it as an alternative route for energy recovery from sludge in the wastewater treatment plant or otherwise use the gasification of fossil fuels, such as power plants integrated gasification combined cycle (IGCC) generating electricity from fossil fuels. This synthesis gas obtained after the gasification is cleanly burned later in a gas turbine to produce electricity.

The heat required for gasification of the sludge in wastewater treatment plant itself may be obtained by combustion of biogas, and $\mathrm{CO}_{2}$ (gasifier agent) coming from the flue gases from the engine generator, which would access hot to the gasifier, reducing energy requirements. The fuel gas obtained could feed back into the gasifier to supply the heat required and the remainder to the combustion chamber of the dryer reducing the need of natural gas or co-fed with biogas in biogas generator sets. This would reduce the cost derived from consumption of natural gas, which is currently around $100,000 € /$ month, a proposal for maximum economic performance of the facilities that makes them viable and attractive from the point of view of exploitation.

\section{Conclusions}

Regardless of the proposed solutions in the coming years, dependence on fossil fuels to sustain economic development will remain so it is necessary to find technological solutions that reduce environmental pollution due to the emission of gaseous pollutants, and to seek alternative fossil fuels.

However, to make our energy sources affordable, in a safe and friendly environment requires exactly the same actions: energy efficiency, no matter which of them we focus on more. From this point of view, giving an energy value to a waste, which as such is annoying, must be positive from these three points of view.

The use of sludge as alternative fuel is a net saving in $\mathrm{CO}_{2}$ emissions because the emissions from biomass are not accounted, whereas if it is deposited in 
landfills, emissions due to uncontrolled fermentation itself are counted. The use of biosolids in cement kilns is accepted, but it is necessary to control specific parameters such as maximum allowable dose of sludge according to their characteristics, the range of temperature and types of fuel used, as well as the final properties of the cement. It is estimated that the use of 1 ton of sludge involves a reduction of 1.28 tons of $\mathrm{CO}_{2}$, without including the emissions associated with transport [16].

On the other hand, the transformation of dried and partially digested sludge into synthesis gas with a higher heat of combustion is an alternative to their use in cement kilns. Also, this technology would take the total energy contained in the sludge in the sewage itself, reducing the costs associated with transport by $38 \%$ (inorganic matter cannot be enhanced through the wastewater treatment plant). The disadvantage of this route is the need for investment of the filter in the right technology, but energy (HHV of the gas is well above the sludge) and environmentally (would reduce emissions from transport and the gases would be used to combustion engines in the gasification) would be most advantageous.

In 2004 the emissions of $\mathrm{CO}_{2}$-e in Spain exceeded 33\% the expected value due to a unreal adjustment between emission reduction and economic benefit, among other factors. All the policies and advances in technology and management that lead to harmony between these two parameters will be beneficial. In particular, those that have major impact on the development of any way of recovering energy from waste and the development of sinks of $\mathrm{CO}_{2}$-e is expected.

\section{Acknowledgement}

This work has been possible thanks to the financial support of the BIOVALOR project (Euskadi 09 Programme - Basque Government).

\section{References}

[1] R. Saidur, E. A. Abdelaziz, A. Demirbas, M. S. Hossain and S. Mekhilef, "A review on biomass as a fuel for boilers," Renewable and Sustainable Energy Reviews, vol. 15, pp. 2262-2289, 6, 2011.

[2] R. M. Baldwin, K. A. Magrini-Bair, M. R. Nimlos, P. Pepiot, B. S. Donohoe, J. E. Hensley and S. D. Phillips, "Current Research on Thermochemical Conversion of Biomass at the National Renewable Energy Laboratory," Applied Catalysis B: Environmental.

[3] A. Domínguez, J. A. Menéndez, M. Inguanzo and J. J. Pís, "Production of bio-fuels by high temperature pyrolysis of sewage sludge using conventional and microwave heating," Bioresour. Technol., vol. 97, pp. 1185-1193, 7, 2006.

[4] S. Shams Yazdani and R. Gonzalez, "Engineering Escherichia coli for the efficient conversion of glycerol to ethanol and co-products," Metab. Eng., vol. 10, pp. 340-351, 11, 2008. 
[5] R. Iranpour, R. Palacios, H. H. J. Cox and V. Abkian, "Solving fecal coliform growth/reactivation in biosolids during full-scale post-digestion processes," vol. 52, pp. 283-288, 2005.

[6] J. Á. Siles López, Martín Santos,María de los Ángeles, A. F. Chica Pérez and A. Martín Martín, "Anaerobic digestion of glycerol derived from biodiesel manufacturing," Bioresour. Technol., vol. 100, pp. 5609-5615, 12, 2009.

[7] M. Sami, K. Annamalai and M. Wooldridge, "Co-firing of coal and biomass fuel blends," Progress in Energy and Combustion Science, vol. 27, pp. 171-214, 2001.

[8] K. R. G. Hein and J. M. Bemtgen, "EU clean coal technology-cocombustion of coal and biomass," Fuel Process Technol, vol. 54, pp. 159$169,3,1998$.

[9] N. S. Harding and B. R. Adams, "Biomass as a reburning fuel: a specialized cofiring application," Biomass Bioenergy, vol. 19, pp. 429-445, 12, 2000.

[10] A. V. Ensinas, S. A. Nebra, M. A. Lozano and L. M. Serra, "Analysis of process steam demand reduction and electricity generation in sugar and ethanol production from sugarcane," Energy Conversion and Management, vol. 48, pp. 2978-2987, 11, 2007.

[11] A. Bhattacharya, D. Manna, B. Paul and A. Datta, "Biomass integrated gasification combined cycle power generation with supplementary biomass firing: Energy and exergy based performance analysis," Energy, vol. 36, pp. 2599-2610, 5, 2011.

[12] C. Bang-Møller and M. Rokni, "Thermodynamic performance study of biomass gasification, solid oxide fuel cell and micro gas turbine hybrid systems," Energy Conversion and Management, vol. 51, pp. 2330-2339, 11, 2010.

[13] C. Bang-Møller, M. Rokni and B. Elmegaard, "Exergy analysis and optimization of a biomass gasification, solid oxide fuel cell and micro gas turbine hybrid system," Energy, vol. 36, pp. 4740-4752, 8, 2011.

[14] A. Demirbas, "Sustainable cofiring of biomass with coal," Energy Conversion and Management, vol. 44, pp. 1465-1479, 6, 2003.

[15] D. Fytili and A. Zabaniotou, "Utilization of sewage sludge in EU application of old and new methods--A review," vol. 12, pp. 116-140, 2008.

[16] M. A. Larrubia, L. J. Alemany, M. C. Herrera, C. Palacios, M. O. GuerreroPrez, M. C. Ramírez and I. Malpartida, "Valorización energética de biosólidos: algunos aspectos económicos y ambientales en la EDAR Guadalhorce (Málaga),” RESIDUOS, vol. 17, pp. 60, 2007.

[17] L. Fryda, K. Panopoulos, P. Vourliotis, E. Pavlidou and E. Kakaras, "Experimental investigation of fluidised bed co-combustion of meat and bone meal with coals and olive bagasse," Fuel, vol. 85, pp. 1685-1699, 9, 2006.

[18] K. Suksankraisorn, S. Patumsawad, P. Vallikul, B. Fungtammasan and A. Accary, "Co-combustion of municipal solid waste and Thai lignite in a fluidized bed," Energy Conversion and Management, vol. 45, pp. 947-962, 4, 2004. 
112 Waste Management and the Environment VI

[19] A. Nordin, "Optimization of sulfur retention in ash when cocombusting high sulfur fuels and biomass fuels in a small pilot scale fluidized bed," Fuel, vol. 74, pp. 615-622, 4, 1995.

[20] A. Demirbas, "Combustion characteristics of different biomass fuels," Progress in Energy and Combustion Science, vol. 30, pp. 219-230, 2004. 